\title{
Manga As Educational Material for Children About Environment Through Hayao Miyazaki's Manga Nausicaa: Of the Valley of The Wind
}

\author{
Rukma Kawentar ${ }^{1 *}$, and Redyanto Noor ${ }^{2}$ \\ ${ }^{1}$ Master of Literature, Faculty of Humanities, Diponegoro University, Indonesia \\ ${ }^{2}$ Master of Literature, Faculty of Humanities, Diponegoro University, Indonesia
}

\begin{abstract}
Manga is the name for comics originating from Japan. As a form of literary work, many still consider this type of literary work as cheap literature. Therefore, through this research, the writer will see how manga, considered cheap literature, can be a very effective learning media, especially those related to environmental themes. The object of study of this research is the manga Nausicaa: Of The Valley Of The Wind by Hayao Miyazaki. Meanwhile, this object itself will be studied using the concept of reading comics and the approach of ecocriticism. Through these concepts and approaches, it can be seen that manga media will make readers more interested in these literary works and can quickly grasp the moral messages contained in work. It can be concluded that this media is a very effective educational medium to convey moral messages to readers.
\end{abstract}

\section{Introduction}

Manga Manga is one type of comic form. Manga is a comic that comes from Japan and has slightly different characteristics from other forms of comics. Before explaining manga, it is good to explain comics in general first. Comics, according to McCloud, are pictures or symbols that are arranged systematically and aim to convey information and get responses from readers [1]. McCloud also explained that the images contained in comics are a beneficial communication medium in conveying messages from the comic itself [1]. The primary difference between comics and manga is in how to read them. Comics are read from left to right, while manga, on the other hand, is read from right to left. Manga as comics originating from Japan usually contains cultures related to the country of origin.

According to Frey and Fischer, comics and similar forms of work can be used as practical teaching tools [2]. There are three reasons why comics can be used as compelling educational materials. First, the reader's interest in this type of work is very high compared to other types of literary works. Second, the comic medium is easier to find, and the price is

* Corresponding author: rukma.kawentar@gmail.com 
also not high. Third, this type of literary work is relatively easier to read and understand [3]. At the beginning of its development, comics were considered a cheap literary medium. This developed because, at first, comics in western countries were only limited to superhero comics and were more for children's readers. In its development, the types of comics are getting more and more genres, not limited to superhero comics. The development of these comics can also be felt in the development of the manga genre in Japan. In Japan, even manga has different names according to the gender of the reader or the time of publication.

Japan has a unique culture which is also reflected in its manga. One of the Japanese cultures often found in manga stories is about human life that depends on the natural environment. One of the manga that shows the relationship between humans and the natural environment is the manga Nausicaa: Of the Valley of The Wind by Hayao Miyazaki. The manga was published from 1982 to 1994, telling the story of a princess named Nausicaa from a small kingdom called Valley of the Wind who lived in a dystopian period where the ecosystems on earth contained deadly poisons to humans. Humans cannot survive without using a special mask to filter out the toxins contained in the earth's ecosystem. In addition to the danger of natural disasters, the kingdom inhabited by Princess Nausicaa is also threatened by a war between kingdoms [4].

This article will raise the theme of ecocriticism in Hayao Miyazaki's manga Nausicaa: of The Valley of the Wind. The problem that will be seen in this article is about how manga as a material object can function as learning material about the natural environment shown in Miyazaki's manga.

\section{Ecocritic in the manga Nausicaa: of The Valley of the Wind}

The word ecocriticism comes from two words, namely ecology and criticism. Ecology can be interpreted as a scientific study that discusses the relationship patterns of plants, animals, and humans to each other and their environment [5], while criticism means judging. In the world of literature itself, there is a branch of science called literary criticism, which can be interpreted as a process of analysis, assessment and interpretation of a literary work as a form of art. So, it can be concluded that literary ecocriticism is the analysis, assessment and interpretation of a literary work related to the pattern of relationships between plants, animals and humans with the surrounding natural environment. Garrard argues that ecocriticism is part of literary ecology [6]. Literary ecology is an extrinsic science of literature that studies the relationship between literature and its environment. In contrast, literary ecocriticism is a branch of literature that critically evaluates the literature on an ecological basis. So it can be seen that literary ecology does not always contain environmental criticism in literature, while literary ecocritic focuses more on social criticism about the environment in literary works. Problems in ecocriticism and literary ecology need scientific analysis through the relationship between knowledge of cultural ecology. Garrard reveals that knowledge of ecology itself is the focus of the analysis of ecocritic [6]. Garrard also argues that ecocriticism is an interdisciplinary study linked to other sciences such as culture, philosophy, sociology, psychology and history [6]. According to Endraswara itself, the main focus of this ecocritical study can be divided into three main focuses, namely: (1) examining what environments can shape or influence literature, (2) examining the environment described in literary works, (3) examining the environmental reception of the literary works that are ecological. By explaining its primary focus, it can be seen that ecocritical studies always have an ecological context in them [7]. 


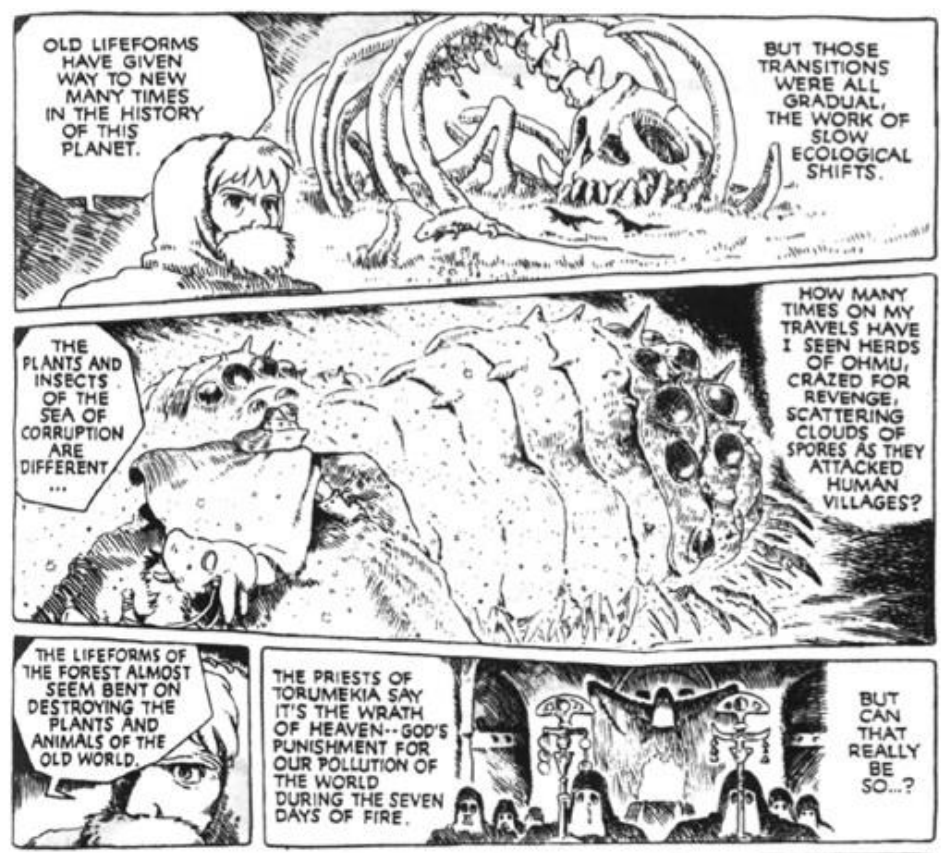

Fig. 1 Natural Environment in the Manga.

In Miyazaki's manga itself, it is shown how the natural environment on earth is very worrying where humans cannot freely enjoy the natural environment as before a natural disaster that caused dystopia that occurred on earth. From the picture above, it is explained that the world in this manga has its dominant ecosystem, which is very complex and extensive. The existence of these ecosystems threatens human survival. The poisonous forest and the dangerous insects that live in the forest are reasons for human fear of the state of the natural environment. There is also a story that has been passed down from generation to generation about the narrative that humans have been punished for the sins they have committed against the earth, and the people in this manga believe that the current state of the natural environment is a form of revenge on the earth for human treatment of the natural environment. In the manga story, it is finally known that the poisonous forest has a significant role in the balance of nature on earth. Nausicaa discovers the truth when trapped in the forest that the plants in the forest have a function to absorb toxins in the air on earth so that the natural state of the environment in the manga story is kept in balance. 


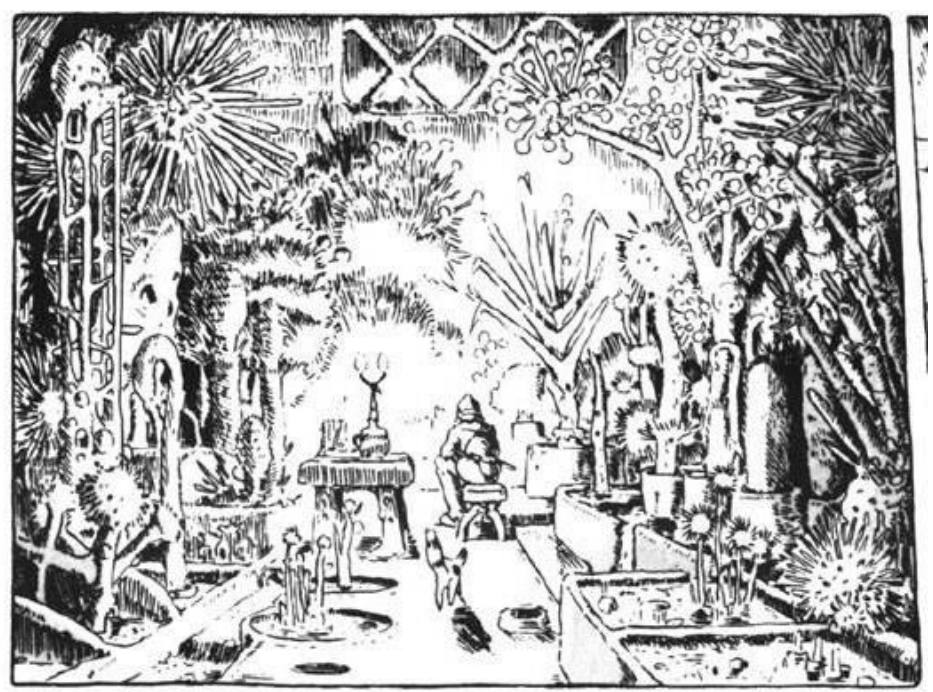

Fig. 2 Nausicaa's Laboratory.

The picture above [8] shows how Nausicaa's efforts are to investigate further the existence of plants in the surrounding environment so that the main functions of the plants found in the vicinity can be known. The events in the manga that are more worrying than the natural environment are about the existence of wars between kingdoms that involve humans and harm the natural environment where the kingdom is located. The war between the kingdoms has damaged the natural environment in this manga story. It is shown when attacking the Valley of the Wind kingdom, and the enemy kingdom also destroys the plants in the Valley of the Wind kingdom by cutting down all the trees in the kingdom and burning them until nothing remains. The behaviour carried out by the enemy kingdom shows how the human perspective in this manga towards the natural environment. Humans show their ignorance of the environment, while on the other hand, they also show their fear of the natural environment that can threaten human existence. The Nausicaa character in the story shows the opposite attitude to most humans in this manga. By risking her life, Nausicaa believes that the natural environment must be preserved because she knows that humans and the natural environment cannot be separated. Humans and the natural environment have causal relationships that are interrelated with one another that can affect their lives

\subsection{Moral Values of the Manga Nausicaa: of the Valley of the Wind}

From the explanation of ecocriticism in the previous subchapter, it can be seen that there are many moral messages contained in this manga, especially those related to ecology. The manga Nausicaa: of the Valley of the Wind by Hayao Miyazaki contains a strong critique of the destruction of the natural environment caused by humans. Humans in this manga are described as creatures who do not care about the natural environment, which causes natural disasters that harm humans themselves. The relationship between humans and nature in this manga does not show a balance of life and even tends to be the opposite. Humans see nature as a disaster and grow a sense of fear of nature itself which also grows their indifferent attitude towards the existence of nature. In contrast, nature itself is shown as not caring about human survival, where in fact, the depiction of this indifference is a form of human treatment of nature itself. The humans in this manga also indirectly show that the humans in the manga are selfish creatures. Through the wars between these kingdoms, it can be seen how these 
wars also arise due to the greed of humans for power which consequently also affects the surrounding natural environment.

The criticism of the natural environment in this manga is Miyazaki's way of showing how the natural conditions in the future will be damaged due to human actions. As the main character, Nausicaa is an essential character in this critique of the destruction of nature. Nausicaa is one of the keys that distinguishes the depiction of the relationship between humans and nature in this manga. Nausicaa believes that coexistence with nature is something that humans must carry out. She does not see the natural environment only from the point of view of nature that can damage humans, but she also sees the benefits that nature provides for humans. Nausicaa is positioned not to side with humans or nature. He shows how the balance of life can be achieved when humans can appreciate the existence of the natural environment as an ecosystem in which humans live.

\subsection{The Advantages of Medium Manga in Conveying a Moral Message About Ecocritic}

The manga Nausicaa: of the Valley of the Wind by Hayao Miyazaki is a famous manga with preserving nature. Miyazaki himself is pretty famous for his works that show the harmonization of the natural environment with his characters in the story, especially in the form of animated films [9]. In contrast to Miyazaki's animated film, Miyazaki's manga shows the impact of human actions that do not care about the environment and makes it easier for readers to imagine and think about the importance of preserving the natural environment. As previously explained, according to previous research by Frey and Fischer, the comic medium as educational material has its advantages compared to learning books that are specifically intended as educational material. Manga or comics whose primary function is intended as entertainment can also be used as educational material for their readers [10]. Manga or comics themselves as entertainment books have a more comprehensive range of readers and are relatively affordable than other learning books.

The explanation above shows that even though manga or comics were once seen as cheap literary works, these types of literary works have advantages compared to other types of literary works. The moral message contained in a comic can be easily found and observed by readers because the reading process of a comic depends on symbols in the form of letters and is also represented by images that support the story of the work. The image from the comic helps the process of reading a work easier because it makes it easier for the reader to focus on imagining.

The ecocriticism in the manga Nausicaa: of the Valley of the Wind by Hayao Miyazaki is also very helpful in delivering to readers because of Miyazaki's comic media. The reader's focus on the moral message to be conveyed in the manga Nausicaa: of the Valley of the Wind is easier to accept than if through other media such as films. The film is a medium that requires greater concentration to understand the content of the story because the process of reading films uses the human senses more than the process of reading comics. The depiction of the destruction of nature contained in the manga Nausicaa: of the Valley of the Wind is displayed clearly with the help of pictures in the manga. From pictures that show the destruction of nature, readers are invited to develop their imagination further, not only limited to what is depicted in the manga. Through this comic medium, it is hoped that the theme of destroying nature in manga can be widely conveyed to the broader community. Through comics, it is also hoped that the moral message about preserving the natural environment in this manga can have a deep impression and be more accessible for readers to remember because reading comics use greater emotional involvement than reading ordinary books that only contain writing.writing. 


\section{Conclusion}

This article shows how criticism of the relationship between humans and nature is told in Hayao Miyazaki's manga Nausicaa: of the Valley of the Wind. The manga shows a picture of the future when humans no longer respect the natural environment and how nature responds to human attitudes. Manga as a medium is one of the right tools to convey the moral message that a writer wants to express. The form of manga which consists of pictures arranged systematically to form a storyline is very helpful in the understanding process of the reader. From the analysis of the previous chapter, three conclusions can be drawn about the advantages of manga as a medium to convey moral messages, especially about ecocriticism. First, manga has a broader market segmentation than ordinary educational books so that the moral message the author wants to convey to readers also becomes more comprehensive in scope. Second, manga as a medium of communication can easily convey moral messages to readers but can also develop the reader's imagination process further about the moral messages that the author wants to convey. The last one is about reading a manga or comic that requires greater emotional involvement than an ordinary book which causes the reader to process the results of the reading more quickly and remember them more easily. Through the three advantages of manga as a medium for education, it can be seen that as educational material, manga is very suitable for use in conveying the moral messages contained in it, including in delivering education about preserving the natural environment as shown in the manga Nausicaa: of the Valley. the Wind by Hayao Miyazaki.

\section{References}

1. McCloud, Scott. Understanding Comics: The Invisible Art. New York: Harper Collins \& Kitchen Sink Press. (1994)

2. Frey, N., \& Fisher, D. Using graphic novels, anime, and the Internet in an urban high school. English Journal, 93(3), 19-25. (2004)

3. Wright, G., 8c Sherman, R. Let's create a comic strip. Reading Improvement, 36(2), 6672. (1999).

4. Inaga, Shigemi. "Miyazaki Hayao's Epic Comic Series: "Nausicaä in the Valley of the Wind:" An Attempt at Interpretation." Japan Review, no. 11: 113-27. (1999)

5. Harsono, Siswo. "Ekokritik: Kritik Sastra Berwawasan Lingkungan”. Jurnal Kajian Sastra (32)1: 31-50. Semarang: Fakultas Sastra Universitas Diponegoro. (2008)

6. Garrad, Greg. Ecocriticism. London and New York: Routedge. (2004)

7. Endraswara, Suwardi. Ekokritik Sastra: Konsep, Teori dan Terapan. Yogyakarta: Morfalingua. (2016)

8. Miyazaki, Hayao. Nausicaa: of the Valley of the Wind. Tokyo: Tokuma Shoten. (19821994)

9. McCarthy, Helen. Hayao Miyazaki Master of Japanese Animation. Berkeley, Ca: Stone Bridge Press. (1999)

10. Williams, Rachel Marie-Crane. "Image, Text, and Story: Comics and Graphic Novels in the Classroom." Art Education, vol. 61, no. 6, National Art Education Association, pp. 13-19. (2008) 